\title{
Best papers from the CIB Facilities Management Conference 2014
}

\author{
Jensen, Per Anker
}

Published in:

Facilities

Link to article, DOI:

10.1108/F-06-2015-0042

Publication date:

2015

Document Version

Peer reviewed version

Link back to DTU Orbit

Citation $(A P A)$ :

Jensen, P. A. (2015). Best papers from the CIB Facilities Management Conference 2014. Facilities, 33(11/12). https://doi.org/10.1108/F-06-2015-0042

\section{General rights}

Copyright and moral rights for the publications made accessible in the public portal are retained by the authors and/or other copyright owners and it is a condition of accessing publications that users recognise and abide by the legal requirements associated with these rights.

- Users may download and print one copy of any publication from the public portal for the purpose of private study or research.

- You may not further distribute the material or use it for any profit-making activity or commercial gain

- You may freely distribute the URL identifying the publication in the public portal

If you believe that this document breaches copyright please contact us providing details, and we will remove access to the work immediately and investigate your claim. 


\section{Guest editorial}

\section{Best Papers from the CIB Facilities Management Conference 2015}

The international conference on Facilities Management (FM) in Copenhagen 21-23 May 2014 attracted 90 participants, including academics from around the world and professionals from the Nordic countries of Europe (Jensen, 2014). The CIB FM conference is arranged biannually by CIB Working Commission W070 Facilities Management and Maintenance. The conference in 2015 was organised in collaboration with W111 Usability and W118 Clients and Users. This joint conference amongst working commissions focused on stakeholders in the built environment, the importance of increased openness, and how FM can create value for all stakeholders. The conference venue was the Technical University of Denmark, Lyngby Campus, Copenhagen. The local organizer was Centre for Facilities Management - Realdania Research, which is headed by this guest editor, who also was chairman of the organizing and scientific committees.

The three day conference included 38 research papers, which were presented at 12 parallel sessions. Two of these sessions were part of a special one day practice track, which besides research presentations also included presentations by invited speakers from practice in Denmark and Norway. The themes covered a diverse mix of topics within the broad field of FM. Two topics had particular strong attention. One topic was sustainability, where climate change was the focus of some papers. The other topic was user issues, including usability and user experiences. This topic clearly reflects the conference being arranged in collaboration between W070 and the working commissions W111 Usability and W118 Clients and Users.

This special issue includes articles, which are based on a selection of the best papers presented at the conference. All together nine papers were selected based on the double blind reviews of the conference papers. The reviewers were asked to indicate whether papers should be considered for a best paper award. The guest editor made the selection from these indications as well as from considerations of a thematic and geographical distribution of the papers. All nine papers have been developed into journal articles and have gone through the normal double blind review process of Facilities. Six of the papers are included in this special issue. The remaining three papers will be published in coming volumes of the journal.

The first paper, by Jones, Desai, Mulville and Jones, was one of the contributions concerning sustainability in terms of taking the effects of climate change into account in the formation of long term built asset management strategies. The paper presents an original approach employing a combination of backcasting and forecasting principles and illustrates the methodology on a new university building in the UK. At the closing session of the conference this paper achieved the best paper award sponsored by Facilities. The selection of the paper for the award was uncomplicated as it was the only paper, which both reviewers recommended to be considered as the best paper.

The second paper, by Tu, also concerns sustainability but in a more narrow sense in terms of energy management. The paper applies an advanced quantitative method called 'data envelopment analysis'. Like the first paper the method is used in a case study from a university, but it concerns a specific department in a Taiwan university, and the aim is to assist individual departments in their energy management tasks. The methodology allows facility managers to assess and compare the energy efficiency scores 'among different spaces', to further review the energy efficiency of a space 'over time'; and to recognize the benchmark cases and pursue actions for energy improvements.

The third paper, by Brinkø, Nielsen and van Meel, is also related to sustainability but in a quite different way by investigating the novel topic of 'shared space'. Thereby the paper is related to the new and fast developing "sharing economy". The paper develops a typology of shared use of facilities consisting of four distinct archetypes of sharing between different people, building owners 
and organisations. The typology is derived by use of five discriminators or variables related to: what, when, why, who and how space is shared, based on an analysis of 20 examples from Europe, USA and Australia. The use of the typology is illustrated by a case from Dublin. The typology establishes an interesting foundation for research on this new research topic concerning a development of increasing importance in the practice of FM.

The fourth paper, by Rytkönen, Nenonen, Österlund and Kojo, is one of the many papers related to usability, and it is from Finland like the majority of these papers. The paper focuses on facilitating interdisciplinary learning communities and is based on a case study of five intrinsic interdisciplinary space development projects in a university campus. It tries to answer, how topdown and bottom-up spatial development project processes aiming at interdisciplinary collaboration, are conducted and managed in the same university. The role of campus management seems to be shifting towards facilitating both types of processes by finding a right balance in five dimensions of: approach, motivation, budget, type of outcome, and added value.

The fifth paper, by Riratanaphong and van der Voordt, concerns workplace management and focusses on measuring the added value of workplace change in theory and practice. The paper compares various performance measurement systems from literature with current performance management in practice in order to get a better understanding of the complex relationships between workplace change, added value and organisational performance. The empirical basis consists of two case studies from Thailand and one from the Netherlands. The findings show that many performance criteria and key performance indicators from literature are used in practice, but except for the Balanced Scorecard no performance measurement system from literature is literally applied. The paper proposes a step-by-step procedure to facilitate the selection of prioritized key performance indicators.

The sixth paper, by Banyani and Then, focuses on FM as an industry and presents a framework for evaluating industry maturity called the 'Integrated Feeder Factors Framework (I3F). The framework includes the following areas: organisation practice, business environment, supply market, professional bodies, education, and research. The applicability of the framework has been tested on the FM industry in five countries: Denmark, Hong Kong, Norway, Tanzania and the UK. The result shows that the maturity of the FM industry is highest in the UK and lowest in Tanzania, while Denmark, Hong Kong and Norway are generally at the same level in between but with some notable differences.

Per Anker Jensen Guest Editor

\section{About the guest editor}

Per Anker Jensen is professor in Facilities Management at The Technical University of Denmark and head of the externally funded Centre for Facilities Management - Realdania Research. He holds the degrees of MSc in Civil Engineering, PhD and MBA. Besides research and teaching he has 20 years of experience from practice as consultant, project manager and facilities manager. His research interest concerns how briefing, design, development and management of physical facilities can add value to users and organisations.

\section{References}

Jensen, P.A. (ed.): Proceedings of CIB Facilities Management Conference: Using Facilities in an Open World - Creating Value for All Stakeholders. Joint CIB W070, W111 \& W118 Conference. Technical University of Denmark, Copenhagen, 21-23 May 2014. Centre for Facilities Management - Realdania Research, DTU Management Engineering, and Polyteknisk Forlag, May 2014. Print version can be ordered at: http://www.polyteknisk.dk/home/Soegeresultat?q=Facilities. Electronic version is available free for download at www.cfm.dtu.dk and from CIB. 